\title{
How Communion and Agentic Beliefs Predict Technology-Supported Formal and Informal Learning
}

\section{The Implications for Educational Technology}

\author{
https://doi.org/10.3991/ijet.v17i04.27249 \\ Andreja Istenic ${ }^{1,2,3(\varpi)}$, Maja Lebenicnik ${ }^{1}$ \\ ${ }^{1}$ University of Primorska, Koper, Slovenia \\ ${ }^{2}$ University of Ljubljana, Ljubljana, Slovenia \\ ${ }^{3}$ Kazan Federal University, Kazan, Russia \\ andreja.istenic7@gmail.com
}

\begin{abstract}
Recent pandemic circumstances facilitated a rapid shift to online learning. The home and school environments are now intertwined, so the connection of formal and informal environments is inevitable. The studies of online learning resources (OLR) use before the pandemic shed light on studies of pandemic school-home learning nexus. This paper examines the higher education situation before the pandemic. We discuss students' use $(\mathrm{N}=1323)$ of technology in learning in light of the role of educational technology, taking a sociocultural perspective of learning in the broader context of formal and informal socio-cultural contexts and practices of interaction with humans and tools. An analysis of OLR identified three factors. The first two factors involved overlapping formal and informal learning, while the third was clearer collaboration and interaction for formal learning. The three factors were analysed using hierarchical regression to assess predictors for technology use, focussing on three factors. (1) Beliefs about learning with technology, examined within the twodimensional structure of agency and communion. (2) Self-regulated learning, which is critical for informal learning and also received significant attention in formal learning. Since it is claimed that teachers are not ready for integrating informal learning, we examined (3) teachers as role models as predictors of ICT use in learning. Finally, (4) since obstacles were among the primary critical factors in previous related studies, we examined whether they still have predictive power. The findings indicate that communion and agentic beliefs are the strongest predictors.
\end{abstract}

Keywords-higher education, educational technology, socio-cultural theory, informal learning, formal learning, agency and communion, self-regulated learning

\section{Introduction}

Recent pandemic circumstances facilitated a rapid shift to online learning. The home and school environments are now intertwined, so the connection of formal and 
informal environments was inevitable. Studies of online learning resources (OLR) use before the pandemic shed light on studies of pandemic school-home learning nexus. In this paper, we examine the situation in higher education before the pandemic.

Digital practices and digital skills develop in socio-culturally situated practice. The socio-cultural theory of learning explains learning as interaction in the cultural context involving social contexts (e. g. peers, adults) and tools [1]. Learning is regarded as participation in communities of practice where situated learning is shared, and knowledge is co-constructed [2], utilising literacy as the primary means of meaningmaking [3] and operationalisation of cultural tools by mediation and internalisation in the process of the internal plane of mental activity [4].

Digital practices transform reading and writing by engaging online forms of social collaborations [5]. The definition of digital literacy has transited from the conceptualisation of digital media as "technology" or "information" [6] to considering it as social practice involving reading, writing and multimodal meaning-making using digital technologies [7].

Digital technologies saturate students' lives and offer opportunities to blur the boundaries between formal and informal learning [8]. Digital technology has been recognised as a bridge between formal and informal learning and linking university students' school-to-home activities [8]. Selwyn [9] highlights the relevance of university students' lived practice with technology for students' engagement and technology integration in university teaching and learning has been recognised. Research findings, however, indicate the lack of examining the use of digital technology in informal learning and its impact on learning outcomes [10]. Khaddaget and Knezek [11] examined students' technology-supported informal learning to develop a pedagogy to connect formal and informal learning. ICT-supported practices are communication- and interest-driven [12] and support learners in designing their learning environments according to preferences and needs [13]. Digital skills developed in informal learning contribute to student performance [10]. Therefore, research in educational technology requires connectedness with students' life world.

\subsection{Learning across contexts and the notions of boundary crossing and legitimate peripheral participation}

Beckett and Hager [14] state that the main characteristics of informal learning are contextual-, activity- and experience-based, arising in situations where learning is not the primary activity, initiated by the learner and in many cases collaborative. As with formal learning objectives, structures of content and process are pre-defined, but in informal learning, the driving incentive is the learner's self-directedness and autonomy [15]. In contrast with traditional classroom instruction, online learning requires self-regulatory skills from the learner [16]. Self-directed learning has been an important topic in instructional design in the systems of formal learning. Bruner and Rogers facilitated the movement for learners' autonomy and self-directedness at the elementary and secondary levels [17]. It has also been identified as an important success factor at a post-secondary level [16]. 
Sawchuk [18] discusses the situated nature of informal learning, contesting models of situated learning and introducing the power thesis, questioning the issue of agency and freedom as identified by Livingston [19] and Knud Illeris et al.'s [20] model, guided by technical-organisational, socio-cultural and individual factors.

Lave and Wenger [2] argue for learning as situated learning that occurs in the context where it is used. The process of becoming a member of a community of practice takes the form of learning through peripheral participation in a community of practice. Learning attained in boundary-crossing between academic and work contexts is an important resource for learning. Engeström, Engeström, and Kärkkäinen [21] examine it, referring to boundary learning as facing norms, knowledge and power. Communities of inquiry supported by instructional technology are seen as a means to transform higher education [22].

Border pedagogy was introduced by Giroux [23], referring to epistemological, cultural, political and social borders that structure and are structured by discourse and power. He referred to the empowerment of students for the agency to become border crossers and challenged institutions to give power to students to articulate their experiences and epistemologies in their language and culture [23].

Socio-cultural theory examines learning as culturally mediated in a society where the primary tool of meaning-making is literacy and the importance of how literacy is thought about. Giroux addresses the question of a pedagogy to support students' literacy skills development so they can become agents in boundary space [23]. Students' cultures and how students create cultural forms and forms of knowledge applying digital technology are important realities to be integrated into the official curriculum 23], [3], [6]. In digitalised social practices, digital media are discussed as important facilitators for learning across contexts in boundary space. The role of the learner's agency and ownership of learning in a boundary area is discussed in the context of didactisation or pedagogisation of life [24]. Making the social media adopted by younger generations part of mainstream school culture and adopting them into formal education, bringing academia closer to young people's lives opens questions of legitimacy, which Stefton-Green and Erstad [24] conceptualise as following young people in their learning in everyday life.

Informal learning and formal learning are more entwined and could occur simultaneously; that is, informal learning could also occur when conducting formal learning [15]. In our study, we examine how students perceive and use technology for formal and informal learning. Research indicates the potential of digital media to connect learning across contexts of home, peer relations, free time, and school [25].

\subsection{Self-regulated learning}

ICT practices are more student-driven, and students manifest a high degree of selfregulation in its use. Studies indicate the connection between self-regulated learning and social media use [26]. According to Pintrich [27], [28] and Schunk, selfregulatory activities influence learners' achievements, and individuals' self-regulation is a process in the relationship between learners and their environment. The social dimension is essential in self-regulatory activities, which, according to Zimmerman's 
model influenced by Bandura, consist of environmental, behavioural and personal dimensions [29]. Boekaerts [30] engages social resources in motivational strategies in her model.

Castaneda and Selwyn [31] argue that educational technologies in higher education should be examined in their use for self-regulated learning because technology is an essential element of higher education pedagogy [32]. DiBenedeto and Schunk [32] examine self-regulated learning as motivational and self-efficacy perceptions through a socio-cultural view.

Barak's [33] findings indicate that students learning online have better selfregulative learning skills. We examine how ICT use for self-regulated learning is perceived and its predictive role for technology use in formal and informal learning. We focus on ICT use for cognitive, metacognitive and resource management strategies [27], [30], [34].

\subsection{Beliefs}

Beliefs are associations that people establish between an attitudinal object and various features they ascribe to it [35]. In technology-supported learning, the social dimension is becoming increasingly important. The values, motives and relation to social context are based, according to Bakan [36], on two dimensions; agency and communion. The focus of this study is the exploration of beliefs about ICT use in learning, using a two-dimensional structure and its prediction of ICT supported learning.

In line with Bakan's [36] findings, the agency dimension was oriented towards competency, instrumentality, and intellectual desirability. The communion dimension was oriented towards social desirability and interdependent-self construct. These two dimensions, agency and communion, could also be interpreted by the twodimensional structure articulated by Asch [37]; intellectual versus social desirability. Agentic beliefs pursue interest of the self, striving to individuate and efficiently attain one's goals [37]. Communion beliefs refer to the integration of self in a social unit, taking care of the interests of others [37] belonging to a community. Thus, communion is a predictor of involvement in social relations and the interests of others [37]. In this study, we examine how the agentic and communion beliefs predict ICT use in learning and whether it confirms the agentic beliefs as stronger predictors for selfinterest and communal beliefs for social engagement. The findings of Abele \& Wojciszke [37] also showed a correlation of communal beliefs to a certain extent with self-interest, indicating that society is indispensable in social functioning.

Beliefs affect the learning process, learning outcomes, assessment and performance. We examine them within two dimensions, agency and communion. Examples of agency items: relative advantage (personalisation), effectiveness (better follow trends, better grades), preferability (more fun, more creative, more curious), applicability (better collaboration), flexibility (access to learning anywhere), specificity (getting access to more information than any other source, access to information) [38]. Examples of communion items: observability (others - visibility among academics 
and peers), relative advantage (the interaction in academic environment, sense of belonging) [38].

\subsection{Educational technology and the use of online educational resources}

The definition of educational technology from 1994 states, "Instructional technology is theory and practice of design, development, utilisation, management and evaluation of process and resources for learning" [39]. M. Spector [40] discusses the roles of educational technology in personalisation, providing feedback, supporting social learning, diminishing boundaries, alternative teaching methods, enhancing the role of stakeholders, providing learning beyond formal learning, and promoting evidencebased policy.

Educational technology addresses learning in a broad perspective as follows:

- It establishes learning in environments that are not primarily intended for learning;

- It supports the transitions between formal and informal learning;

- It includes tools and uses specific to life and professional practices;

- ICT skills acquired through non-formal learning in students' lived experiences are transferred to formal learning;

- Student-driven self-regulated learning in informal potential brings the potential for formal learning.

Online learning resources overcome the metaphors of knowledge as acquisition and knowledge as participation metaphor [41]. Understanding knowledge as situated and participatory knowledge, [2] refer to digital literacy as social practice. The notion of online learning resources for informal learning refers to learning processes and learning outcomes considered to develop outside the formal curriculum [42].

\subsection{Teacher model}

Technology-supported informal learning practices have the potential for formal learning. Research findings indicate limited influence on students' self-directed learning outside classrooms [43]. Teachers are role models as experts in the field, especially when supporting cognitive, affective and social learning experiences [44]. Teachers' actual use of technology in the classroom does not, however, have much influence on students' technology use [43].

Research questions:

- What are students' beliefs about ICT use for learning, and how do they predict students' ICT use for learning?

- Is students' ICT use in formal learning entwined with ICT use for informal learning?

- How do students use ICT for self-regulated learning, and how does this predict students' ICT use for learning?

- What is the predictive role of teacher as a model, and what are obstacles for students' ICT use for learning? 
Hypotheses:

- H: Student's beliefs about ICT in learning reveal a two-dimensional structure: the agentic and communion dimensions.

- H: Communion beliefs predict ICT use in the social context, and agentic beliefs predict ICT use for personal interests.

- H: Students' ICT use for formal learning is entwined with ICT use for informal learning.

- H: Self-regulative learning is strongly represented in informal learning.

- H: Communion and agentic beliefs also strongly influence a model when other predictors for students' ICT use are included: ICT supported self-regulated learning, teacher model, and obstacles.

\section{Methods}

We surveyed students of the University of Ljubljana, the largest Slovene university, with $67.3 \%$ of the student population from all Slovene regions. In 2017, about 40.000 students received an invitation to take part in the survey. In total, 2325 students responded, of whom 1359 students completed the whole survey. Following initial analyses, this paper presents the data from 1323 students.

\subsection{Instruments and data analysis}

We developed an instrument for the survey. It includes the following scales:

- Online learning resources use designed by authors [45] based on technology classifications [46], [47], [48], [49], [58] and classification of learner's roles [50].

- Beliefs scale designed by reviewing beliefs and attitudes scales on ICT use for learning [38], [51], [52], [53], and two scales on motives for using the Internet [54], [55].

- Barriers scale designed based on literature review [34] and aligned with the model by Seale et al. [56].

- ICT for self-regulated learning based on the Motivated Strategies for Learning Questionnaire [57] and a review and classification of OLR [34].

- Teacher as a Role Model scale, designed by authors [59] based on [43].

The data processing was conducted using SPSS 25.0. We performed principal axis factoring (PAF) to establish clear, reliable factors for each category of variables and discover the latent structure of measured constructs. Descriptive statistics (M, SD) and Spearman's $r$ coefficients of factors. Hierarchical linear regression analyses were also performed. 


\section{Findings and discussion}

\subsection{Factor analysis and reliability assessment}

In all cases, Principal Axis Factoring was performed with Oblimin rotation when there were multifactor solutions. Oblimin rotation was applied, as no orthogonal factor solution was expected. Scree plots were used to make decisions on the number of extracted factors, which is an appropriate method for large samples [60]. In some cases, several items had to be dropped before the initial EFA because their correlation with other items was too high, resulting in determinant values that were too low $(<0.00001)$ [60]. Likewise, some items were dropped after the initial EFA because of cross loading. Solutions with a Kayser-Mayer-Olkin (KMO) value above .7 were applied, and items with factor loadings more or equal to 0.40 were retained [60]. Tables 1-6 present EFA solutions for retained items. A Cronbach alpha higher than 0.70 indicates sufficient item reliability [60].

However, in line with Brown [61], a Cronbach alpha higher than 0.676 was considered to represent acceptable internal reliability. In a few cases with fewer items, in line with Hair et al. [62] and George and Mallary [63], a factor Cronbach alpha higher than 0.60 was accepted for internal reliability. Only factors showing sufficient reliability were used in subsequent analysis.

Results from EFA on items measuring Beliefs about ICT in Learning showed two latent factors (Table 1). The first factor represents agentic beliefs, covering items that represent personalisation and agency in ICT supported learning. Items on the second factor refer to communion beliefs indicating interpersonal dimension in learning.

Table 1. Exploratory factory analysis of students' beliefs about ICT in learning

\begin{tabular}{|c|c|c|c|c|}
\hline Factor & Items & 1 & 2 & $\alpha$ \\
\hline \multirow{10}{*}{$\begin{array}{l}\text { Agentic } \\
\text { beliefs }\end{array}$} & $\begin{array}{l}\text { Using ICT for learning allows me to customise the learning process to } \\
\text { my needs. }\end{array}$ & .721 & & \\
\hline & ICT allows me to learn anywhere. & .675 & & \\
\hline & Learning with ICT is more fun than traditional learning. & .663 & & \\
\hline & $\begin{array}{l}\text { Using the web for learning, I can get access to more information than } \\
\text { with any other source (e.g. books, professors). }\end{array}$ & .652 & & \\
\hline & $\begin{array}{l}\text { On the web, I have access to learning information I could not get } \\
\text { anywhere else. }\end{array}$ & .611 & & \\
\hline & On the web I can better follow trends in my study field. & .596 & & \\
\hline & I am more creative in learning because of ICT use. & .580 & .152 & \\
\hline & I have better grades because of use of ICT for learning. & .572 & .158 & \\
\hline & When I use ICT, I am more curious during learning. & .549 & .176 & \\
\hline & Using ICT for learning allows me better collaboration with others. & .474 & .200 & \\
\hline & $\begin{array}{l}\text { Eigenvalue }=5.603 \\
\% \text { Variance }=43.097\end{array}$ & & & .869 \\
\hline \multirow{3}{*}{$\begin{array}{l}\text { Communion } \\
\text { beliefs }\end{array}$} & Using ICT allows me better personal interaction with academic staff. & & .845 & \\
\hline & Using ICT for learning gives me feelings of belonging to the group. & .134 & .538 & \\
\hline & Others (professors, colleagues) can see positive results when I can use & .249 & .501 & \\
\hline
\end{tabular}




\begin{tabular}{|l|l|l|l|l|}
\hline & ICT for learning. & & & \\
\hline & $\begin{array}{l}\text { Eigenvalue }=1.202 \\
\% \text { Variance }=9.243\end{array}$ & & & $\mathbf{. 7 2 7}$ \\
\hline
\end{tabular}

Extraction method: principal axis factoring. Rotation method: Oblimin with Kaiser normalisation. KMO $=.923$

* Correspond on a scale from 1- completely disagree to -5-completely agree.

${ }^{* *}$ Factor weights of absolute value equal to or larger than .40 are bolded.

In Table 2, two factors were identified, with overlapping formal and informal learning, and in the third, there is more clear collaboration and interaction for the purpose of formal learning.

Table 2. Exploratory factory analysis of ICT supported learning

\begin{tabular}{|c|c|c|c|c|c|}
\hline Factor & Items & 1 & 2 & 3 & $\alpha$ \\
\hline \multirow{14}{*}{$\begin{array}{l}\text { ICT use for social } \\
\text { context for bridg- } \\
\text { ing between } \\
\text { formal and infor- } \\
\text { mal }\end{array}$} & Using news aggregators (RSS feed, e.g. feedly.com etc.) & .636 & .020 & -.091 & \\
\hline & $\begin{array}{l}\text { I post blogs on the web with content from my study field } \\
\text { (for example, long posts on social networks, a stand-alone } \\
\text { blog, use of blog platforms, online weblog writing, etc.) }\end{array}$ & .612 & .009 & -.063 & \\
\hline & $\begin{array}{l}\text { Subscribing to digital newsletters, notifications from } \\
\text { websites with educational content. }\end{array}$ & .580 & -.149 & -.069 & \\
\hline & $\begin{array}{l}\text { I follow the educational content suggested by the computer } \\
\text { recommendation system (for example, on multimedia } \\
\text { platforms, social networks, online news). }\end{array}$ & .565 & -.096 & .160 & \\
\hline & $\begin{array}{l}\text { Sharing information with educational content in social } \\
\text { networks. }\end{array}$ & .545 & .052 & .180 & \\
\hline & Using online tutorials. & .538 & -.148 & -.144 & \\
\hline & $\begin{array}{l}\text { Using web applications for knowledge self-assessment } \\
\text { (e.g. quizzes). }\end{array}$ & .523 & .045 & .012 & \\
\hline & $\begin{array}{l}\text { I'm reading weblogs with content from my study area (eg } \\
\text { blogs, longer logging on social networks). }\end{array}$ & .488 & -.177 & .143 & \\
\hline & $\begin{array}{l}\text { Participating in online discussions (e.g. on social networks, } \\
\text { online forums) related to my study field. }\end{array}$ & .433 & .051 & .270 & \\
\hline & $\begin{array}{l}\text { Using information generated in communication between } \\
\text { online users (e.g. forums, Q\&A websites, comments on } \\
\text { websites etc.) while learning. }\end{array}$ & .408 & -.101 & .226 & \\
\hline & $\begin{array}{l}\text { Using social bookmarking sites (e.g. reddit.com, pinter- } \\
\text { est.com, del.icio.us) to learn from other users about rele- } \\
\text { vant online resources from my study field. }\end{array}$ & .391 & -.162 & .065 & \\
\hline & $\begin{array}{l}\text { When using social media, I create networks (for example, I } \\
\text { add and track people, subscribe to online channels) in order } \\
\text { to access educational content from my study area. }\end{array}$ & .380 & -.250 & .130 & \\
\hline & $\begin{array}{l}\text { Bookmarking websites with educational content from my } \\
\text { study field (e.g. pinterest.com, bookmarking in browsers). }\end{array}$ & .350 & -.222 & .098 & \\
\hline & $\begin{array}{l}\text { Eigenvalue }=10.132 \\
\% \text { Variance }=28.949\end{array}$ & & & & .866 \\
\hline \multirow{3}{*}{$\begin{array}{l}\text { ICT for formal } \\
\text { and informal } \\
\text { learning of inter- } \\
\text { ests and trends }\end{array}$} & $\begin{array}{l}\text { Specific topics from my study, for which I have great inner } \\
\text { interest. }\end{array}$ & -.085 & -.800 & .003 & \\
\hline & $\begin{array}{l}\text { Staying current on trends and developments in my study } \\
\text { field. }\end{array}$ & .081 & -.764 & -.102 & \\
\hline & Developing new skills. & .003 & -.695 & .018 & \\
\hline
\end{tabular}




\begin{tabular}{|c|c|c|c|c|c|}
\hline & Staying current on new technologies. & .076 & -.689 & -.060 & \\
\hline & $\begin{array}{l}\text { Staying current on trends and developments in the field of } \\
\text { my future career }\end{array}$ & .149 & -.683 & -.100 & \\
\hline & $\begin{array}{l}\text { I learn non-intentionally (incidental) during my leisure } \\
\text { time. }\end{array}$ & .013 & -.606 & -.026 & \\
\hline & Hobbies. & -.143 & -.539 & .124 & \\
\hline & $\begin{array}{l}\text { Watching educational videos (e.g. video lectures, anima- } \\
\text { tions). }\end{array}$ & .234 & -.420 & .075 & \\
\hline & $\begin{array}{l}\text { Visiting web portals with educational content from my } \\
\text { study field. }\end{array}$ & .367 & -.387 & .045 & \\
\hline & $\begin{array}{l}\text { Using online databases with scientific and professional } \\
\text { articles while learning. }\end{array}$ & .144 & -.359 & .031 & \\
\hline & $\begin{array}{l}\text { Reading e-books with educational content (e.g. e- } \\
\text { textbooks). }\end{array}$ & .244 & -.357 & .026 & \\
\hline & $\begin{array}{l}\text { Eigenvalue }=2.462 \\
\% \text { Variance }=7.034\end{array}$ & & & & .887 \\
\hline \multirow{7}{*}{$\begin{array}{l}\text { ICT use for col- } \\
\text { laboration in } \\
\text { formal learning }\end{array}$} & $\begin{array}{l}\text { Using synchronous communication e-tools for communi- } \\
\text { cating with other students while learning (e.g. Skype, } \\
\text { Facebook Messages, gTalk, Viber etc.). }\end{array}$ & .022 & .066 & .674 & \\
\hline & $\begin{array}{l}\text { Actively participating in online community from my study } \\
\text { field where I know the majority of the members (e.g. } \\
\text { classroom Facebook group). }\end{array}$ & .017 & .118 & .667 & \\
\hline & $\begin{array}{l}\text { Sharing files with others for the purpose of learning (e.g. } \\
\text { Dropbox, Google Drive, e-mail etc.). }\end{array}$ & .135 & -.089 & .454 & \\
\hline & $\begin{array}{l}\text { Help-seeking from colleagues and professors (e.g. over } \\
\text { communication tools, social networks, e-mail etc.) }\end{array}$ & .395 & .167 & .417 & \\
\hline & Using web search engines while learning. & -.097 & -.344 & .386 & \\
\hline & $\begin{array}{l}\text { Using digital material provided by my university depart- } \\
\text { ment. }\end{array}$ & -.088 & -.103 & .385 & \\
\hline & $\begin{array}{l}\text { Eigenvalue }=1.867 \\
\% \text { Variance }=5.335\end{array}$ & & & & .734 \\
\hline
\end{tabular}

Extraction method: principal axis factoring. Rotation method: Oblimin with Kaiser normalisation. KMO = .939

* Correspond on a scale from 1- completely disagree to -5-completely agree.

** Factor weights of absolute value equal to or larger than .40 are bolded.

The original scale, ICT for self-regulated learning, applied items for cognitive (rehearsal, inquiry), metacognitive self-regulation (organising, planning and monitoring) and resource management strategies (peer learning, help-seeking). It was designed based on the Motivated Strategies for Learning Questionnaire [57] and a review and classification of OLR [34].

In Table 3, we can see that the first factor included cognitive and resource management strategies. Thus, the cognitive strategy is connected with metacognitive and not with resource management strategies as in the original instrument [57]. The two items, rehearsal and inquiry, were, however, dropped as not having indicated sufficient loadings. The remaining items reflected resource management strategies in a social dimension of external sources, teacher or peer learning. 
Paper-How Communion and Agentic Beliefs Predict Technology-Supported Formal and Informal...

Table 3. ICT for self-regulated learning

\begin{tabular}{|c|c|c|c|c|}
\hline Factor & Items & 1 & 2 & $\alpha$ \\
\hline \multirow{3}{*}{$\begin{array}{l}\text { External sources teacher } \\
\text { or peer learning }\end{array}$} & $\begin{array}{l}\text { Help-seeking from colleagues and professors (e.g. over } \\
\text { communication tools, social networks, e-mail etc.). }\end{array}$ & .771 & & \\
\hline & $\begin{array}{l}\text { Peer learning with colleagues (e.g. group discussions, } \\
\text { joint products etc.). }\end{array}$ & .647 & & \\
\hline & $\begin{array}{l}\text { Eigenvalue }=2.597 \\
\% \text { Variance }=42.710\end{array}$ & & & .676 \\
\hline \multirow{3}{*}{$\begin{array}{l}\text { Metacognitive } \\
\text { strategies }\end{array}$} & $\begin{array}{l}\text { Organising material, concepts and ideas during the } \\
\text { learning (e.g. using e-tools for preparing mind maps, } \\
\text { notes etc.). }\end{array}$ & & -.778 & \\
\hline & $\begin{array}{l}\text { Planning and monitoring of the learning process (e.g. } \\
\text { setting learning goals, knowledge self-testing etc.). }\end{array}$ & & -.652 & \\
\hline & $\begin{array}{l}\text { Eigenvalue }=1.003 \\
\% \text { Variance }=16.710\end{array}$ & & & 681 \\
\hline
\end{tabular}

Extraction method: principal axis factoring. Rotation method: Oblimin with Kaiser normalisation. KMO $=.732$

${ }^{*}$ Correspond on a scale from 1 - completely disagree to -5-completely agree.

${ }^{* *}$ Factor weights of absolute value equal to or larger than .40 are bolded.

The teacher as role model scale integrates three main areas: affection (i.e., encouragement and enhancing awareness for technology use), capacity (i.e., use recommendations and tips), and behavioural support (i.e., the teacher serves as a model for technology use) (Lai, 205). As indicated in Table 4, the single factor solution represents a combination of areas.

Table 4. Exploratory factory analysis of teacher model for ICT in learning

\begin{tabular}{|c|l|c|c|}
\hline Factor & \multicolumn{1}{|c|}{ Items } & $\mathbf{1}$ & $\boldsymbol{\alpha}$ \\
\hline \multirow{5}{*}{$\begin{array}{l}\text { Teacher } \\
\text { model }\end{array}$} & Teachers are successful in using ICT for teaching. & $\mathbf{. 8 1 2}$ & \\
\cline { 2 - 5 } & Teachers are using innovative technological solutions in teaching. & $\mathbf{. 8 0 9}$ & \\
\cline { 2 - 5 } & Teachers are models for how to resolve problems that may occur during ICT use. & $\mathbf{. 7 6 2}$ & \\
\cline { 2 - 5 } & I can see enthusiasm from teachers for using technological solutions. & $\mathbf{. 7 4 8}$ & \\
\cline { 2 - 5 } & Teachers are at least as competent as I am in using ICT. & $\mathbf{. 6 8 8}$ & \\
\hline \multirow{2}{*}{} & $\begin{array}{l}\text { Eigenvalue }=3.336 \\
\text { \% Variance }=66.722\end{array}$ & & $\mathbf{. 8 7 4}$ \\
\hline
\end{tabular}

Extraction method: principal axis factoring. Rotation method: Oblimin with Kaiser normalisation. KMO = .843

* Correspond on a scale from 1- completely disagree to -5-completely agree.

** Factor weights of absolute value equal to or larger than .40 are bolded.

The single factor solution integrates seven obstacles connected with personal and contextual situations (see Table 5).

Table 5. Exploratory factory analysis of obstacles in ICT supported learning

\begin{tabular}{|c|l|c|c|}
\hline Factor & \multicolumn{1}{|c|}{ Items } & $\mathbf{1}$ & $\boldsymbol{\alpha}$ \\
\hline \multirow{4}{*}{ Obstacles } & Insufficient technological equipment. & $\mathbf{. 6 8 3}$ & \\
\cline { 2 - 5 } & I would need additional training. & $\mathbf{. 6 7 8}$ & \\
\cline { 2 - 5 } & Because websites and applications are not designed to meet my way of access & $\mathbf{. 6 6 4}$ & \\
\hline
\end{tabular}


Paper-How Communion and Agentic Beliefs Predict Technology-Supported Formal and Informal...

\begin{tabular}{|l|l|c|c|}
\hline & $\begin{array}{l}\text { and usage (e.g. navigation on-page, disturbing elements, incompatibility with } \\
\text { alternative hardware equipment etc.). }\end{array}$ & & \\
\cline { 2 - 4 } & Negative personal beliefs. & $\mathbf{. 6 5 4}$ & \\
\cline { 2 - 4 } & High prices of ICT. & $\mathbf{. 6 3 2}$ & \\
\cline { 2 - 4 } & Because using ICT draws attention to me and makes me feel uncomfortable. & $\mathbf{. 6 2 3}$ & \\
\cline { 2 - 4 } & Different preferences for learning. & $\mathbf{. 5 8 8}$ & \\
\hline & $\begin{array}{l}\text { Eigenvalue }=3.809 \\
\text { \% Variance }=47.612\end{array}$ & & $\mathbf{. 8 3 9}$ \\
\hline
\end{tabular}

Extraction method: principal axis factoring. Rotation method: Oblimin with Kaiser normalisation. KMO $=.882$

${ }^{*}$ Correspond on a scale from 1- completely disagree to -5-completely agree.

** Factor weights of absolute value equal to or larger than .40 are bolded.

\subsection{Descriptive statistics and correlational analysis}

Table 6 presents descriptive statistics (M, SD) for average scores on each construct. The lowest means are associated with items measuring usage of specific ICT tools for establishing the social context for bridging between formal and informal learning $(M=1.90)$ and obstacles in ICT use for learning $(M=2.55)$. The highest means are from items measuring personal beliefs about ICT (the agentic beliefs) (M= 3.84), and the second-highest is ICT use for self-regulated metacognitive learning strategies $(M=3.53)$.

Table 6 presents Spearman's $r$ coefficients for all possible pairings. The items do not appear to be strongly correlated. Although they are conceptually related (as indicated by the numerous moderate and weak correlations), they appear to be statistically independent measures. A negative correlation is indicated in obstacles, moderately negatively correlated with agentic beliefs (-.402) and weakly correlated with ICT use for informal learning for interests and trends (-.309).

Correlations between variables are weak (.2 to .39) or moderate (.4 to .6). In one case, the correlation is strong between ICT use factors for learning, ICT use for social context bridging between formal and informal and ICT for informal learning for interests and trends (.66). A moderate correlation also exists between the first and the third factors, namely, between ICT use for social context bridging between formal and informal and ICT use for collaboration for formal learning support (.53). Higher moderate correlations exist between: ICT use for collaboration for formal learning support and self-regulated learning task engagement (.59); ICT use for informal learning for interests and trends and agency beliefs (.548); communion and agency beliefs (.529); ICT use for informal learning for interests and self-regulated metacognitive learning strategies (.510). The multicorrelation is not identified.

Table 6. M, SD, intercorrelations between measures - Spearman's $r$ for all analysis $(\mathrm{N}=1323)$

\begin{tabular}{|c|c|c|c|c|c|c|c|c|c|c|c|}
\hline & $\mathbf{M}$ & $\mathbf{S D}$ & $\mathbf{1}$ & $\mathbf{2}$ & $\mathbf{3}$ & $\mathbf{4}$ & $\mathbf{5}$ & $\mathbf{6}$ & $\mathbf{7}$ & $\mathbf{8}$ & $\mathbf{9}$ \\
\hline 1 & 1.90 & .62 & 1.00 & $.664^{* *}$ & $.533^{* *}$ & $.383^{* *}$ & $.450^{* *}$ & $.387^{* *}$ & $.456^{* *}$ & $.057^{*}$ & $-.155^{* *}$ \\
\hline 2 & 3.21 & .73 & $.664^{* *}$ & 1.00 & $.453^{* *}$ & $.273^{* *}$ & $.548^{* *}$ & $.380^{* *}$ & $.510^{* *}$ & .019 & $-.309^{* *}$ \\
\hline
\end{tabular}




\begin{tabular}{|l|c|c|c|c|c|c|c|c|c|c|c|}
\hline 3 & 3.42 & .72 & $.533^{* *}$ & $.453^{* *}$ & 1.00 & $.367^{* *}$ & $.457^{* *}$ & $.592^{* *}$ & $.446^{* *}$ & $.084^{* *}$ & $-.217^{* *}$ \\
\hline 4 & 2.54 & .80 & $.383^{* *}$ & $.273^{* *}$ & $.367^{* *}$ & 1.00 & $.520^{* *}$ & $.290^{* *}$ & $.330^{* *}$ & $.254^{* *}$ & $-.051^{* *}$ \\
\hline 5 & 3.84 & .76 & $.450^{* *}$ & $.548^{* *}$ & $.457^{* *}$ & $.520^{* *}$ & 1.00 & $.364^{* *}$ & $.481^{* *}$ & $.085^{* *}$ & $-.402^{* *}$ \\
\hline 6 & 3.06 & .84 & $.387^{* *}$ & $.380^{* *}$ & $.592^{* *}$ & $.290^{* *}$ & $.346^{* *}$ & 1.00 & $.408^{* *}$ & $.062^{*}$ & $-.197^{* *}$ \\
\hline 7 & 3.53 & 1.01 & $.465^{* *}$ & $.510^{* *}$ & $.446^{* *}$ & $.330^{* *}$ & $.481^{* *}$ & $.408^{* *}$ & 1.00 & $.131^{* *}$ & $-.280^{* *}$ \\
\hline 8 & 3.47 & .81 & $.057^{*}$ & .019 & $.084^{* *}$ & $.254^{* *}$ & $.085^{* *}$ & $.062^{*}$ & $.131^{* *}$ & 1.000 & $.019^{* *}$ \\
\hline 9 & 2.55 & .81 & $-.155^{* *}$ & $-.309^{* *}$ & $-.217^{* *}$ & -.051 & $-.402^{* *}$ & $-.197^{* *}$ & $-.280^{* *}$ & .019 & 1.00 \\
\hline
\end{tabular}

${ }^{* *}$ Correlation is significant at the 0.01 level (2-tailed).

* Correlation is significant at the 0.05 level (2-tailed).

Factors: (1) ICT use for social context for bridging between formal and informal; (2) ICT for formal and informal learning of interests and trends; (3) ICT use for collaboration in formal learning; (4) Communion beliefs; (5) Agency beliefs; (6) Self-regulated learning task engagement; (7) Self-regulated metacognitive learning strategies; (8) Teacher model; (9) Obstacles.

\subsection{Hierarchical linear regression analyses}

In the communion dimension, we examined the interaction in the academic environment, sense of belonging, visibility among academic staff and peers. Therefore, in the regression model, we put communion beliefs first to see how much other factors add to this one. Finally, we examined learning beliefs connected to personalisation, ubiquity, creativity, inquiry, fun, and achievements/results in the agentic dimension.

The first factor (ICT for social context bridging between formal and informal), presented in Table 7, reflects social context for integrating informal learning. In informal self-regulative learning, metacognitive strategies are important and here present the strongest predictor. Following it are agentic beliefs, communion beliefs and selfregulated learning external sources teacher or peer learning with almost the same strength. The teacher model has low negative strength.

Table 7. Hierarchical linear regression analyses

\begin{tabular}{|c|c|c|c|}
\hline \multirow[t]{2}{*}{ Predictor } & \multicolumn{3}{|c|}{ ICT for social context bridging between formal and informal } \\
\hline & $\boldsymbol{B}$ & $S E_{b}$ & Beta \\
\hline Constant & 1.122 & .052 & \\
\hline Communion beliefs & .102 & .006 & $.398^{* *}$ \\
\hline Step 1 & $\begin{array}{c}\mathrm{R}^{2} \text { adj (Stepl) }=.157, \\
\mathrm{p}=.000\end{array}$ & $\mathrm{R}^{2}$ change $=.158$ & $\begin{array}{c}\mathrm{F}(1,1323)=248.338 \\
\mathrm{p}<.000\end{array}$ \\
\hline Constant & .411 & .077 & \\
\hline Communion beliefs & .054 & .007 & $.210^{* * *}$ \\
\hline Agentic beliefs & .031 & .003 & $.344^{* *}$ \\
\hline Step 2 & $\begin{array}{c}\mathrm{R}^{2} \text { adj }{ }^{(\text {Step2 } 2)}=.240, \\
\mathrm{p}=.000\end{array}$ & $\mathrm{R}^{2}$ change $=.083$ & $\begin{array}{c}\mathrm{F}(2,1322)=210.120 \\
\mathrm{p}<.000\end{array}$ \\
\hline Constant & .164 & .079 & \\
\hline Communion beliefs & .045 & .007 & $.173^{* *}$ \\
\hline Agentic beliefs & .026 & .003 & $.284^{* *}$ \\
\hline $\begin{array}{l}\text { Self-regulated learning } \\
\text { task engagement }\end{array}$ & .072 & .008 & $.234^{* *}$ \\
\hline
\end{tabular}


Paper-How Communion and Agentic Beliefs Predict Technology-Supported Formal and Informal...

\begin{tabular}{|c|c|c|c|}
\hline Step 3 & $\begin{array}{c}\mathrm{R}^{2} \text { adj }{ }^{(\text {Step3) }}=.287 \\
\mathrm{p}=.000\end{array}$ & $\mathrm{R}^{2}$ change $=.048$ & $\begin{array}{c}\mathrm{F}(3,1321)=178.762 \\
\mathrm{p}<.001\end{array}$ \\
\hline Constant & .060 & .077 & \\
\hline Communion beliefs & .041 & .007 & $.159^{* *}$ \\
\hline Agentic beliefs & .017 & .003 & $.191^{* *}$ \\
\hline $\begin{array}{l}\text { Self-regulated learning } \\
\text { task engagement }\end{array}$ & .050 & .008 & $.162^{* *}$ \\
\hline $\begin{array}{l}\text { Self-regulated } \\
\text { metacognitive strategies }\end{array}$ & .047 & .005 & $.256^{* *}$ \\
\hline Step 4 & $\begin{array}{c}\mathrm{R}^{2} \text { adj (Step 4) }=.332, \\
\mathrm{p}=.000\end{array}$ & $\mathrm{R}^{2}$ change $=.045$ & $\begin{array}{c}\mathrm{F}(4,1320)=165.397, \\
\mathrm{p}<.000\end{array}$ \\
\hline Constant & .198 & .093 & \\
\hline Communion beliefs & .046 & .007 & $.177^{* *}$ \\
\hline Agentic beliefs & .017 & .003 & $.186^{* *}$ \\
\hline $\begin{array}{l}\text { Self-regulated learning } \\
\text { task engagement }\end{array}$ & .049 & .008 & $.161 * *$ \\
\hline $\begin{array}{l}\text { Self-regulated } \\
\text { metacognitive strategies }\end{array}$ & .048 & .005 & $.262^{* *}$ \\
\hline Teacher model & -.010 & .004 & $-.063^{*}$ \\
\hline Step 5 & $\begin{array}{c}\mathrm{R}^{2} \text { adj }{ }^{(\operatorname{Step} 5)}=.335, \\
\mathrm{p}=.007\end{array}$ & $\mathrm{R}^{2}$ change $=.004$ & $\begin{array}{c}\mathrm{F}(5,1319)=134.390, \\
\mathrm{p}<.05\end{array}$ \\
\hline Constant & .077 & .121 & \\
\hline Communion beliefs & .043 & .007 & $.169^{* *}$ \\
\hline Agentic beliefs & .018 & .003 & $.202^{* *}$ \\
\hline $\begin{array}{l}\text { Self-regulated learning } \\
\text { task engagement }\end{array}$ & .050 & .008 & $.163^{* *}$ \\
\hline $\begin{array}{l}\text { Self-regulated } \\
\text { metacognitive strategies }\end{array}$ & .049 & .005 & $.267^{* *}$ \\
\hline Teacher model & -.010 & .004 & $-.064^{*}$ \\
\hline Obstacles & .004 & .003 & .039 \\
\hline Step 6 & $\begin{array}{c}\mathrm{R}^{2} \text { adj }{ }^{(\operatorname{Step} 6)}=.336, \\
\mathrm{p}=.119\end{array}$ & $\mathrm{R}^{2}$ change $=.001$ & $\begin{array}{c}\mathrm{F}(6,1318)=112.520, \\
\mathrm{p}>.05\end{array}$ \\
\hline
\end{tabular}

In the communion dimension, we examined the interaction in the academic environment, sense of belonging, visibility among academic staff and peers. Therefore, in the regression model, we put communion beliefs first to see how much other factors add to this one. Finally, we examined learning beliefs connected to personalisation, ubiquity, creativity, inquiry, fun, and achievements/results in the agentic dimension.

The first factor (ICT for social context bridging between formal and informal), presented in Table 8, reflects social context for integrating informal learning. In informal self-regulative learning, metacognitive strategies are important and here present the strongest predictor. Following it are agentic beliefs, communion beliefs and selfregulated learning external sources teacher or peer learning with almost the same strength. The teacher model has low negative strength. 
Paper-How Communion and Agentic Beliefs Predict Technology-Supported Formal and Informal...

Table 8. Regression analyses of predictors for ICT supported learning - Factor 1: ICT for social context bridging between formal and informal

\begin{tabular}{|c|c|c|c|}
\hline \multirow{2}{*}{ Predictor } & \multicolumn{3}{|c|}{ ICT for social context bridging between formal and informal } \\
\hline & $B$ & $S E_{b}$ & Beta \\
\hline Constant & 1.122 & .052 & \\
\hline Communion beliefs & .102 & .006 & $.398^{* *}$ \\
\hline Step 1 & $\begin{array}{c}\mathrm{R}^{2} \text { adj }{ }_{\mathrm{p}}^{(\text {Step } 1)}=.157 \\
\mathrm{p}=.000\end{array}$ & $\mathrm{R}^{2}$ change $=.158$ & $\begin{array}{c}\mathrm{F}(1,1323)=248.338, \\
\mathrm{p}<.000\end{array}$ \\
\hline Constant & .411 & .077 & \\
\hline Communion beliefs & .054 & .007 & $.210^{* *}$ \\
\hline Agentic beliefs & .031 & .003 & $.344^{* *}$ \\
\hline Step 2 & $\begin{array}{c}\mathrm{R}^{2} \operatorname{adj}^{(\mathrm{Step} 2)}=.240 \\
\mathrm{p}=.000\end{array}$ & $\mathrm{R}^{2}$ change $=.083$ & $\begin{array}{c}\mathrm{F}(2,1322)=210.120, \\
\mathrm{p}<.000\end{array}$ \\
\hline Constant & .164 & .079 & \\
\hline Communion beliefs & .045 & .007 & $.173^{* *}$ \\
\hline Agentic beliefs & .026 & .003 & $.284^{* *}$ \\
\hline $\begin{array}{l}\text { Self-regulated learning } \\
\text { task engagement }\end{array}$ & .072 & .008 & $.234^{* *}$ \\
\hline Step 3 & $\begin{array}{c}\mathrm{R}^{2} \text { adj }{ }^{(\text {Step } 3)}=.287 \\
\mathrm{p}=.000\end{array}$ & $\mathrm{R}^{2}$ change $=.048$ & $\begin{array}{c}\mathrm{F}(3,1321)=178.762, \\
\mathrm{p}<.001\end{array}$ \\
\hline Constant & .060 & .077 & \\
\hline Communion beliefs & .041 & .007 & $.159^{* *}$ \\
\hline Agentic beliefs & .017 & .003 & $.191^{* *}$ \\
\hline $\begin{array}{l}\text { Self-regulated learning } \\
\text { task engagement }\end{array}$ & .050 & .008 & $.162^{* *}$ \\
\hline $\begin{array}{l}\text { Self-regulated } \\
\text { metacognitive strategies }\end{array}$ & .047 & .005 & $.256^{* *}$ \\
\hline Step 4 & $\begin{array}{c}\mathrm{R}^{2} \operatorname{adj}^{(\text {Step } 4)}=.332 \\
\mathrm{p}=.000\end{array}$ & $\mathrm{R}^{2}$ change $=.045$ & $\begin{array}{c}\mathrm{F}(4,1320)=165.397, \\
\mathrm{p}<.000\end{array}$ \\
\hline Constant & .198 & .093 & \\
\hline Communion beliefs & .046 & .007 & $.177^{* *}$ \\
\hline Agentic beliefs & .017 & .003 & $.186^{* *}$ \\
\hline $\begin{array}{l}\text { Self-regulated learning } \\
\text { task engagement }\end{array}$ & .049 & .008 & $.161^{* *}$ \\
\hline $\begin{array}{l}\text { Self-regulated } \\
\text { metacognitive strategies }\end{array}$ & .048 & .005 & $.262^{* *}$ \\
\hline Teacher model & -.010 & .004 & $-.063^{*}$ \\
\hline Step 5 & $\begin{array}{c}\mathrm{R}^{2} \text { adj }{ }^{(\text {Step 5) }}=.335 \\
\mathrm{p}=.007\end{array}$ & $\mathrm{R}^{2}$ change $=.004$ & $\begin{array}{c}\mathrm{F}(5,1319)=134.390, \\
\mathrm{p}<.05\end{array}$ \\
\hline Constant & .077 & .121 & \\
\hline Communion beliefs & .043 & .007 & $.169^{* *}$ \\
\hline Agentic beliefs & .018 & .003 & $.202^{* *}$ \\
\hline $\begin{array}{l}\text { Self-regulated learning } \\
\text { task engagement }\end{array}$ & .050 & .008 & $.163^{* *}$ \\
\hline $\begin{array}{l}\text { Self-regulated } \\
\text { metacognitive strategies }\end{array}$ & .049 & .005 & $.267^{* *}$ \\
\hline
\end{tabular}


Paper-How Communion and Agentic Beliefs Predict Technology-Supported Formal and Informal...

\begin{tabular}{|l|c|c|c|}
\hline Teacher model & -.010 & .004 & $-.064^{*}$ \\
\hline Obstacles & .004 & .003 & .039 \\
\hline Step 6 & $\begin{array}{c}\mathrm{R}^{2} \text { adj (Step 6) } \\
\mathrm{p}=.119\end{array}$ & $\mathrm{R}^{2}$ change $=.001$ & $\begin{array}{c}\mathrm{F}(6,1318)=112.520, \\
\mathrm{p}>.05\end{array}$ \\
\hline
\end{tabular}

The second factor (ICT for formal and informal learning of interests and trends) presented in Table 9 reflects personal interests, informal and formal. As with interests, agentic beliefs are significant, and here represent the strongest predictor. As with informal learning, self-regulative metacognitive learning strategies are important, here in second place, and also very strong. Self-regulated learning external sources teacher or peer learning is not as strong. The teacher model, obstacles and communion beliefs have similar low negative strengths.

Table 9. Regression analyses of predictors for ICT supported learning - Factor 2: ICT for formal and informal learning of interests and trends

\begin{tabular}{|c|c|c|c|}
\hline \multirow{2}{*}{ Predictor } & \multicolumn{3}{|c|}{ ICT for formal and informal learning of interests and trends } \\
\hline & $B$ & $S E b$ & Beta \\
\hline Constant & 29.342 & .740 & \\
\hline Communion beliefs & .883 & .092 & $.254^{* *}$ \\
\hline Step 1 & $\begin{array}{c}\mathrm{R} 2 \operatorname{adj}(\text { Step } 1)=.064, \\
\mathrm{p}=.000\end{array}$ & R2change $=.065$ & $\begin{array}{c}\mathrm{F}(1,1323)=91.484 \\
\mathrm{p}<.000\end{array}$ \\
\hline Constant & 14.450 & 1.023 & \\
\hline Communion beliefs & -.129 & .098 & -.037 \\
\hline Agentic beliefs & .654 & .034 & $.534^{* *}$ \\
\hline Step 2 & $\begin{array}{c}\text { R2 adj (Step2) }=.264, \\
\text { p=.000 }\end{array}$ & R2change $=.201$ & $\begin{array}{c}\mathrm{F}(2,1322)=238.542, \\
\mathrm{p}<.000\end{array}$ \\
\hline Constant & 11.349 & 1.054 & \\
\hline Communion beliefs & -.248 & .096 & $-.071^{*}$ \\
\hline Agentic beliefs & .586 & .034 & $.478^{* *}$ \\
\hline $\begin{array}{l}\text { Self-regulated learning } \\
\text { task engagement }\end{array}$ & .902 & .102 & $.218^{* *}$ \\
\hline Step 3 & $\begin{array}{c}\text { R2 adj }(\text { Step3 })=.305, \\
\text { p }=.000\end{array}$ & R2change $=.041$ & $\begin{array}{c}\mathrm{F}(3,1321)=194.434, \\
\mathrm{p}<.000\end{array}$ \\
\hline Constant & -.299 & .092 & $-.086^{*}$ \\
\hline Communion beliefs & .464 & .035 & $.379^{* *}$ \\
\hline Agentic beliefs & .5833 & .103 & $.141^{* *}$ \\
\hline $\begin{array}{l}\text { Self-regulated learning } \\
\text { task engagement }\end{array}$ & .682 & .066 & $.274^{* *}$ \\
\hline $\begin{array}{l}\text { Self-regulated } \\
\text { metacognitive strategies }\end{array}$ & -.299 & .092 & $-.086^{*}$ \\
\hline Step 4 & $\begin{array}{c}\mathrm{R}^{2} \text { adj }{ }_{\mathrm{p}}^{(\mathrm{Step} 4)}=.356 \\
\mathrm{p}=.000\end{array}$ & $\mathrm{R}^{2}$ change $=.052$ & $\begin{array}{c}\mathrm{F}(4,1320)=183.985 \\
\mathrm{p}<.000\end{array}$ \\
\hline Constant & 12.014 & 1.225 & \\
\hline Communion beliefs & -.226 & .095 & $-.065^{*}$ \\
\hline Agentic beliefs & .456 & .035 & $.373^{* *}$ \\
\hline
\end{tabular}


Paper-How Communion and Agentic Beliefs Predict Technology-Supported Formal and Informal...

\begin{tabular}{|c|c|c|c|}
\hline $\begin{array}{l}\text { Self-regulated learning } \\
\text { task engagement }\end{array}$ & .577 & .103 & $.139^{* * *}$ \\
\hline $\begin{array}{l}\text { Self-regulated } \\
\text { metacognitive strategies }\end{array}$ & .689 & .066 & $.281^{* *}$ \\
\hline Teacher model & -.152 & .047 & $-.073^{*}$ \\
\hline Step 5 & $\begin{array}{c}\mathrm{R}^{2} \text { adj }{ }^{(\operatorname{Step} 5)}=.361 \\
\mathrm{p}=.001\end{array}$ & $\mathrm{R}^{2}$ change $=.005$ & $\begin{array}{c}\mathrm{F}(5,1319)=150.267, \\
\mathrm{p}<.05\end{array}$ \\
\hline Constant & -.152 & .047 & $-.073^{*}$ \\
\hline Communion beliefs & 14.499 & 1.596 & \\
\hline Agentic beliefs & -.183 & .096 & -.053 \\
\hline $\begin{array}{l}\text { Self-regulated learning } \\
\text { task engagement }\end{array}$ & .427 & .037 & $.349^{* *}$ \\
\hline $\begin{array}{l}\text { Self-regulated } \\
\text { metacognitive strategies }\end{array}$ & .563 & .103 & $.136^{* *}$ \\
\hline Teacher model & .680 & .066 & $.274^{* *}$ \\
\hline Obstacles & -.148 & .047 & $-.071^{*}$ \\
\hline Step 6 & $\begin{array}{c}\mathrm{R}^{2} \operatorname{adj}^{(\text {Step } 6)}=.363 \\
\mathrm{p}=.016\end{array}$ & $\mathrm{R}^{2}$ change $=.003$ & $\begin{array}{c}\mathrm{F}(6,1318)=126.669, \\
\mathrm{p}=<.05\end{array}$ \\
\hline
\end{tabular}

The third factor (ICT for collaboration in formal learning), presented in Table 10, reflects collaborative formal learning. Self-regulated learning task engagement, external sources, teacher and peer learning are very strong predictors. These are followed by three predictors of similar strength: agentic beliefs, communion beliefs and selfregulated metacognitive strategies. Interestingly, self-regulated learning external sources teachers and peer learning have the strongest predictive power, but teacher modelling does not have significant influence.

Table 10. Regression analyses of predictors for ICT-supported learning - Factor 3: ICT for collaboration in formal learning

\begin{tabular}{|c|c|c|c|}
\hline \multirow{2}{*}{ Predictor } & \multicolumn{3}{|c|}{ ICT for collaboration in formal learning } \\
\hline & $B$ & $S E_{b}$ & Beta \\
\hline Constant & 15.437 & .398 & \\
\hline Communion beliefs & .724 & .050 & $.372^{* *}$ \\
\hline Step 1 & $\begin{array}{c}\mathrm{R}^{2} \text { adj }{ }^{(\text {Step } 1)}=.138 \\
\mathrm{p}=.000\end{array}$ & $\mathrm{R}^{2}$ change $=.139$ & $\begin{array}{c}\mathrm{F}(1,1323)=212.922 \\
\mathrm{p}<.001\end{array}$ \\
\hline Constant & 10.509 & .594 & \\
\hline Communion beliefs & .398 & .056 & $.200^{* *}$ \\
\hline Agentic beliefs & .216 & .020 & $.316^{* *}$ \\
\hline Step 2 & $\begin{array}{c}\mathrm{R}^{2} \text { adj }{ }^{(\text {Step2 })}=.207 \\
\mathrm{p}=.000\end{array}$ & $\mathrm{R}^{2}$ change $=.070$ & $\begin{array}{c}\mathrm{F}(2,1322)=174.269 \\
\mathrm{p}<.001\end{array}$ \\
\hline Constant & 6.373 & .529 & \\
\hline Communion beliefs & .230 & .048 & $.118^{* *}$ \\
\hline Agentic beliefs & .125 & .017 & $.183^{* *}$ \\
\hline $\begin{array}{l}\text { Self-regulated learning } \\
\text { task engagement }\end{array}$ & 1.203 & .051 & $.519^{* *}$ \\
\hline Step 3 & $\mathrm{R}^{2} \operatorname{adj}^{(\text {Step3) }}=.441$ & $\mathrm{R}^{2}$ change $=.233$ & $\mathrm{~F}(3,1321)=348.731$ \\
\hline
\end{tabular}


Paper-How Communion and Agentic Beliefs Predict Technology-Supported Formal and Informal...

\begin{tabular}{|c|c|c|c|}
\hline & $\mathrm{p}=.000$ & & $\mathrm{p}<.001$ \\
\hline Constant & 6.029 & .531 & \\
\hline Communion beliefs & .219 & .048 & $.112^{* *}$ \\
\hline Agentic beliefs & .097 & .018 & $.142^{* *}$ \\
\hline $\begin{array}{l}\text { Self-regulated learning } \\
\text { task engagement }\end{array}$ & 1.131 & .053 & $.488^{* *}$ \\
\hline $\begin{array}{l}\text { Self-regulated } \\
\text { metacognitive strategies }\end{array}$ & .156 & .034 & $.112^{* *}$ \\
\hline Step 4 & $\begin{array}{c}\mathrm{R}^{2} \text { adj }{ }^{(\text {Step } 4)}=.449 \\
\mathrm{p}=.000\end{array}$ & $\mathrm{R}^{2}$ change $=.009$ & $\begin{array}{c}\mathrm{F}(4,1320)=270.621, \\
\mathrm{p}<.001\end{array}$ \\
\hline Constant & 5.990 & .637 & \\
\hline Communion beliefs & .217 & .049 & $.112^{*}$ \\
\hline Agentic beliefs & .098 & .018 & $.142^{* *}$ \\
\hline $\begin{array}{l}\text { Self-regulated learning } \\
\text { task engagement }\end{array}$ & 1.131 & .053 & $.488^{* *}$ \\
\hline $\begin{array}{l}\text { Self-regulated } \\
\text { metacognitive strategies }\end{array}$ & .156 & .034 & $.112^{* *}$ \\
\hline Teacher model & .003 & .025 & .002 \\
\hline Step 5 & $\begin{array}{c}\mathrm{R}^{2} \text { adj }{ }^{(\text {Step } 5)}=.448 \\
\mathrm{p}=.911\end{array}$ & $\mathrm{R}^{2}$ change $=.000$ & $\begin{array}{c}\mathrm{F}(5,1319)=216.337, \\
\mathrm{p}>.05\end{array}$ \\
\hline Constant & 6.745 & .831 & \\
\hline Communion beliefs & .230 & .050 & $.118^{*}$ \\
\hline Agentic beliefs & .089 & .019 & $.129^{* *}$ \\
\hline $\begin{array}{l}\text { Self-regulated learning } \\
\text { task engagement }\end{array}$ & 1.126 & .053 & $.486^{* *}$ \\
\hline $\begin{array}{l}\text { Self-regulated } \\
\text { metacognitive strategies }\end{array}$ & .150 & .035 & $.108^{* *}$ \\
\hline Teacher model & .004 & .025 & .003 \\
\hline Obstacles & -.026 & .019 & -.032 \\
\hline Step 6 & $\begin{array}{c}\mathrm{R}^{2} \text { adj }{ }^{(\text {Step } 6)}=.449 \\
\mathrm{p}=.158\end{array}$ & $\mathrm{R}^{2}$ change $=.001$ & $\begin{array}{c}\mathrm{F}(6,1318)=180.751, \\
\mathrm{p}>.05\end{array}$ \\
\hline
\end{tabular}

\section{Conclusions}

This study reports data gathered before the pandemic and sheds light on studies of the pandemic school-home learning nexus. The pandemic introduced global changes in social-cultural contexts which subsequently influence the formation of the student learning space. Studies of digital learning have tended to focus on student's personal technology use in diverse contexts and for a variety of purposes. Digital learning was assumed to be a boundary crosser between between formal and informal social practices' and a facilitator for the transfer of practices between contexts in support of learning [64].

In this study, we identified the function of ICT in establishing social contexts bridging between formal and informal learning. The main predictor identified was the self-regulative metacognitive learning strategies which are significant for informal 
learning. Therefore, the significance of informal learning which is more selfregulative, may also increase its significance in formal learning. ICT also facilitates the connection of formal and informal interests and trends with agentic beliefs being the primary predictor identified personal agency for interests and trends in ICT use may transit to formal learning. As for bridging between formal and informal learning, the self-regulative metacognitive learning strategies are significant. Further, ICT has the potential for enhancing collaboration in formal learning. The main predictor is again self-regulative learning but in this item, it is task engagement which is essential for collaboration. Future research should address self- regulative learning in diverse learning environments and identify what drives a person's engagement for agency and communion beliefs.

\section{$5 \quad$ References}

[1] L. S. Vigotski, Mind and society. The development of higher psychological process. Cambridge, Massachusetts, London, England: Harvard University Press, 1978. https://doi.org/1 $\underline{0.1017 / \mathrm{CBO} 9780511815355}$

[2] J. Lave, and E. Wenger, Situated learning: legitimate peripheral participation. New York: Cambridge University Press, 1991. https://doi.org/10.4324/9780203299234

[3] G. Kress, Literacy in the new media age. London: Routledge, 2003. https://doi.org/10.4324 19780203299234

[4] I. Engeness, and A. Lund, "Reprint of: Learning for the future: Insights arising from the contributions of Piotr Galperin to the cultural-historical theory," Learning culture and social interaction, vol. 27, 100476, pp. 2020. https://doi.org/10.1016/j.lcsi.2020.100476

[5] S. Ludvigsen, A. Lund, I. Rasmussen, and R. Saljo, Eds. Learning across sites. New tools, infrastructures and practices. Oxford, UK: Routledge, 2011. https://doi.org/10.4324/97802 03847817

[6] D. Buckingham, "Defining digital literacy. What do young people need to know about digital media?" Nordic Journal of Digital Literacy, vol. 4, pp. 21-34, 2015. https://doi.org/10. 18261/ISSN1891-943X-2015-Jubileumsnummer-03

[7] J. Sefton-Green, J., Marsh, O. Erstad, and R. Flewitt, "Establishing a research agenda for the digital literacy practices of young children. A white paper for COST Action IS1410," 2016. Available at: http://digilitey.eu. [Accessed: Nov. 12, 2020].

[8] L. A. Mills, G. Knezek, and F. Khaddage, "Information Seeking, Information Sharing, and going mobile: Three bridges to informal learning," Computers in Human Behavior, vol. 32, pp. 324-334, 2014. https://doi.org/10.1016/j.chb.2013.08.008

[9] N. Selwyn, "The use of computer technology in university teaching and learning: a critical perspective," Journal of Computer Assisted Learning, vol. 23, pp. 83-94, 2007. https://doi. org/10.1111/j.1365-2729.2006.00204.x

[10] T. He, and C. Zhu," Digital informal learning among Chinese university students: the effects of digital competence and personal factors," International Journal of Educational Technology in Higher Education, vol. 14, no. 44, pp. 1-19, 2017. https://doi.org/10.1186/s 41239-017-0082-x

[11] F. Khaddaget, and G. Knezek, "iLearn via mobile technology: A comparison of mobile learning attitudes among university students in two nations, "In Advanced Learning Technologies (ICLT), 2013 IEEE 13th International conference, pp. 256-258, 2013. https://doi. org/10.1109/ICALT.2013.79 
Paper-How Communion and Agentic Beliefs Predict Technology-Supported Formal and Informal...

[12] K. Beckman, S. Bennett, and L. Lockyer, "Understanding students' use and value of technology for learning," Learning, media and technology, vol. 39, no 3, pp. 346-367, 2014. https://doi.org/10.1080/17439884.2013.878353

[13] A. Sangra, and S. Wheeler, "New Informal Ways of Learning: Or Are We Formalising the Informal? In: Informalisation of Education [online dossier]," Universities and Knowledge Society Journal, vol. 10, no. 1, pp. 286-293, 2013. https://doi.org/10.7238/rusc.v10i1.1689

[14] H. Colley, P. Hodkinson, and J. Malcom, Informality and formality in learning:a report for the Learning and Skills Research Centre, University of Leeds: Learning and Skills Research Centre, 2003.

[15] C. P. Cerasoli, G. M. Alliger, J. S. Donsbach, J. E. Mathieu, S. I. Tannenbaum, and K. A. Orvis, "Antecedents and outcomes of informal learning behaviors: A meta-analysis," Journal of Business and Psychology, vol. 33, pp. 203-230, 2017. https://doi.org/10.1007/s1086 9-017-9492-y

[16] Y. C. Kuo, A. Walker, B. R. Belland, K. E. E. Schroder, and Y. T. Kuo, “A case study of integrating interwise: Interaction, Internet self-efficacy, and satisfaction in synchronous online learning environments," The International Review of Research in Open and Distance Learning, vol. 15, no. 1, pp. 161-181, 2014. https://doi.org/10.19173/irrodl.v15i1.16 $\underline{64}$

[17] D. W. Mocker, and G. E. Spear, Lifelong learning: Formal, nonformal, informal, and selfdirected, Columbus, OH: ERIC Clearinghouse for Adult, Career, and Vocational Education, Ohio State University. Moore, 1982.

[18] P. H. Sawchuk, Theories and methods for research on informal learning and work: towards cross-fertilization, Studies in Continuing Education, vol. 30, pp. 1-16, 2008. https://doi.org /10.1080/01580370701628474

[19] D. W. Livingstone, Adults' informal learning: definitions, findings, gaps and future research. In International handbook of educational policy, ed. K. Leithwood, D. Livingstone, A. Cumming, N. Bascia, and A. Datnow. New York: Kluwer, 2005.

[20] K. Illeris, and Associates. Learning in working life. Fredricksberg, DN: Roskilde University Press, 2004.

[21] Y. Engeström, R. Engeström, and M. Kärkkäinen, "Oppiminen ja ongelmanratkaisu monimutkaisissa työprosesseissa," Aikuiskasvatus, vol. 1, pp. 14-27, 1995. https://doi.org/10.3 3336/aik.92303

[22] D. R. Garrison, and A. E. Z. Akyol, "Role of instructional technology in the transformation of higher education.," Journal of Computers Higher Education, vol. 21, pp.19-30, 2009. https://doi.org/10.1007/s12528-009-9014-7

[23] H. A. Giroux, "Border Pedagogy and the Politics of Postmodernism," Social Text, vol. 28, pp- 51-67, 1991. https://doi.org/10.2307/466376

[24] J. Sefton-Green, and O. Erstad, "Researching 'learning lives' a new agenda for learning, media and technology," Learning, Media \& Technology, vol. 42, no. 2, pp. 246-250, 2017. https://doi.org/10.1080/17439884.2016.1170034

[25] K. Kumpulainen, and J. Sefton-Green, "What is connected learning and how to research it?," International journal of learning and media, vol. 4, no 1, pp. 9-24.

[26] N. Dabbagh, and A. Kitsantas, "Personal Learning Environments, Social Media, and Selfregulated Learning: A Natural Formula for Connecting Formal and Informal Learning," Internet and Higher Education, vol. 15, no.1, pp. 3-8, 2012. https://doi.org/10.1016/j.ihedu c.2011.06.002

[27] P. R. Pintrich, "The role of goal orientation in self-regulated learning," In Handbook of self-regulation, M. Boekaerts, P. R. Pintrich, \& M. Zeidner Eds, pp. 451-502. San Diego, CA: Academic, 2000. https://doi.org/10.1016/B978-012109890-2/50043-3 
Paper-How Communion and Agentic Beliefs Predict Technology-Supported Formal and Informal...

[28] D. H. Schunk, "Self-Regulated Learning: The Educational Legacy of Paul R. Pintrich," Educational Psychologist, vol. 40, no. 2, pp. 85-94, 2005. https://doi.org/10.1207/s153269 $\underline{85 \mathrm{ep} 4002 \_3}$

[29] B. J. Zimmerman, “A social cognitive view of self-regulated academic learning,” Journal of Educatonal Psychology, vol. 81, pp. 329-339, 1989. https://doi.org/10.1037/0022-0663. $\underline{81.3 .329}$

[30] M. Boekaerts, "Self-regulated learning at the junction of cognition and motivation," European Psychologist, vol. 2, pp. 100-112, 1996. https://doi.org/10.1027/1016-9040.1.2.100

[31] L. Castañeda, N. Selwyn. More than tools? Making sense of the ongoing digitizations of higher education. International Journal of Educational Technology in Higher Education, vol. 15, no. 22, pp. 1-10, 2018. https://doi.org/10.1186/s41239-018-0109-y

[32] M. K. DiBenedetto, and D. H. Schunk, "Self-efficacy in education revisited through a socialcultural lens," in Big theories revisited 2, G. A. D. Liem \& D. M. McInerney, Eds., pp. 117-139. Charlotte, NC: Information Age, 2018.

[33] M. Barak, R. Hussein-Farraj, and Y. J. Dori, "On-campus or online: Examining selfregulation and cognitive transfer skills in different learning settings," International Journal of Educational Technology in Higher Education, vol. 13, no. 1, pp. 35, 2016. https://doi.o rg/10.1186/s41239-016-0035-9

[34] M. Lebenicnik, and A. Istenic Starcic, "Factors related to the use of online learning resources: The perception of environmental and contextual barriers of students with special educational needs and their peers," in International conference of innovative Technologies in learning 2018 LNCS 11003, T. Wu, Y. Huang, A. Istenic Starcic, R. Shadijev, \& L. Lin, Eds, pp. 1-8, Verlag Berlin, Heidelberg: Springer, 2018b. https://doi.org/10.1007/978-3$\underline{319-99737-7 \quad 35}$

[35] M. Fishbein, and I. Ajzen, Belief, attitude, intention, and behavior: An introduction to theory and research, Reading, MA: Addison-Wesley, 1975.

[36] D. Bakan, The duality of human existence: Isolation and communion in western man, Boston, MA: Beacon, 1966.

[37] A. E. Abele, and B. Wojciszke, "Agency and communion from the perspective of self versus others," Journal of Personality and Social Psychology, vol. 93, pp. 751-763, 2007. https://doi.org/10.1037/0022-3514.93.5.751

[38] J. van Braak, and P. Tearle, "The computer attributes for learning scale (CALS) among university students: Scale development and relationship with actual computer use for learning," Computers in Human Behavior, vol. 23, pp. 2966-2982, 2007. https://doi.org/1 0.1016/j.chb.2006.08.014

[39] B. B. Seels, and R. C. Richey, Instructional technology: The definition and domains of the field, Washington, DC: Association for Educational Communications and Technology, 1994.

[40] J. M. Spector, Foundations of educational technology: Integrative approaches and interdisciplinary perspectives, New York: Routledge, 2012.

[41] S. Paavola, and K. Hakkarainen, "The knowledge creation metaphor - An emergent epistemological approach to learning," Science and Education, vol. 14, no. 6, pp. 535-557, 2005. https://doi.org/10.1007/s11191-004-5157-0

[42] Hart Research Associates, "Falling short? College learning and career success," Association of American Colleges and Universities, 2015, Available at: http://www.aacu.org/leap/ public-opinion-research/2015-survey-results [Accessed December 4, 2007].

[43] C. Lai, "Modelling teachers' influence on learners' self-directed use of technology for language learning outside the classroom," Computers \& Education, vol. 82, pp. 74-83, 2015. https://doi.org/10.1016/j.compedu.2014.11.005 
Paper-How Communion and Agentic Beliefs Predict Technology-Supported Formal and Informal...

[44] K. K. Katyal, and C. W. Evers, "Teacher leadership and autonomous student learning: Adjusting to the new realities," International Journal of Educational Research, vol. 41, pp. 367-382, 2004. https://doi.org/10.1016/j.ijer.2005.08.007

[45] M. Lebenicnik, and A. Istenic Starcic, "The online learning resources definition and students' use in higher education across disciplines," in International conference of innovative technologies in learning 2018 LNCS 11003, T. Wu, Y. Huang, A. Istenic Starcic, R. Shadijev, \& L. Lin , Eds, pp. 1-10, Verlag Berlin, Heidelberg: Springer, 2018a. https://doi. org/10.1007/978-3-319-99737-7_40

[46] D. Churchill, D. "Towards a useful classification of learning objects," Educational technology research development, vol. 55, pp. 479-497, 2007. https://doi.org/10.1007/s11423006-9000-y

[47] R. Culatta, R., and M. Leavitt, "Classification based on similar functionality. Innovative learning, Mind map," 2010 Retrieved from http://innov ative learn ing.com/instr uctio nal_techn ology /categ ories.html

[48] A. C. Graesser, P. Chipman, and B. G. King, "Computer-Mediated technologies," in Handbook of research on educational communications and technology, J. M. Spector, M. D. Merrill, J. van Merriënboer, and M. P. Driscoll, Eds, pp. 211-224, New York, London: Taylor \& Francis Group, 2008.

[49] D. Laurillard, Rethinking university teaching: A conversational framework for the effective use of learning technologies 2nd ed, London: Routledge, 2002. https://doi.org/10.4324 19780203304846

[50] S. Bidarian, S., Bidarian, and A. M. Davoudi, "A model for application of ICT in the process of teaching and learning," Procedia-Social and Behavioral Sciences, vol. 29, pp. 1032-1041, 2011. https://doi.org/10.1016/j.sbspro.2011.11.336

[51] K. Hakkarainen, L. Ilomaki, L., Lipponen, H. Muukkonen, M. Rahikainen, T. Tuominen, , ... E. Lehtinen, "Students' skills and practices of using ICT: Results of a national assessment in Finland," Computers \& Education, vol. 34, pp. 103-117, 2000. https://doi.org/10.1 016/S0360-1315(00)00007-5

[52] C. Lai, Q. Wang, and J. Lei, "What factors predict undergraduate students' use of technology for learning? A case from Hong Kong," Computers \& Education, vol. 59, pp. 569579, 2012. https://doi.org/10.1016/j.compedu.2012.03.006

[53] G. Sang, M. Valcke, J. van Braak, and J. Tondeur, "Student teachers' thinking processes and ICT integration: Predictors of prospective teaching behaviors with educational technology," Computers \& Education, vol. 54, pp. 103-112, 2010. https://doi.org/10.1016/j.co mpedu.2009.07.010

[54] R. LaRose, and M. S. Eastin, A social cognitive theory of internet uses and gratifications: Toward a new model of media attendance. Journal of Broadcasting \& Electronic Media, vol. 48 no. 3, pp, 358-377, 2004. https://doi.org/10.1207/s15506878jobem4803_2

[55] M. Senkbeil, and J. M. Ihme, "Motivational factors predicting ICT literacy: First evidence on the structure of an ICT motivation inventory," Computers \& Education, vol. 108, pp. 145-158, 2017. https://doi.org/10.1016/j.compedu.2017.02.003

[56] J. Seale, E. Draffan, and M. Wald, "Digital agility and digital decision making: conceptualising digital inclusion in the context of disabled learners in higher education," Studies in Higher Education, vol. 35, no. 4, pp. 445-461, 2010. https://doi.org/10.1080/03075070903 $\underline{131628}$

[57] P. R. Pintrich, D. A. F. Smith, T. Garcia, and W. A. McKeachie, Manual for the Use of the Motivated Strategies for Learning Questionnaire (MSLQ), The University of Michigan, Ann Arbor, Michigan, 1991. 
Paper-How Communion and Agentic Beliefs Predict Technology-Supported Formal and Informal...

[58] D. Song, C. J. Bonk, "Motivational factors in self-directed informal learning from online learning" Cogent Education, vol. 3, no.11, pp. 1-111, 2016. https://doi.org/10.1080/23311 $\underline{\text { 86X.2016.1205838 }}$

[59] A. Istenic, Starcic, and M. Lebenicnik, "Investigating university students' perceptions of their educators as role models and designers of digitalized curricula, "Human technology, vol. 16, no. 1, pp, 55-91, 2020. https://doi.org/10.17011/ht/urn.202002242163

[60] A. Field, Discovering Statistics Using IBM SPSS Statistics (4th ed.), Sage, Washington, DC, 2013.

[61] T. A. Brown, Confirmatory factor analysis for applied research, NY: Guilford Press, 2006.

[62] J. F. Hair, W. C. Black, B. J. Babin, and R. E. Anderson, Multivariate data analysis, Pearson College Division, 2010.

[63] D. George, and P. Mallery, SPSS for Windows step by step: A simple guide and reference. 11.0 update 4th ed, Boston: Allyn \& Bacon, 2003.

[64] A. Istenic Starcic, M. Terlevic, L. Lin, and M. Lebenicnik, Designing Learning for Sustainable Development: Digital Practices as Boundary Crossers and Predictors of Sustainable Lifestyles, Sustainability, vol. 10, no. 6, pp. 1-24. https://doi.org/10.3390/su10062030

\section{Acknowledgement}

The authors of the paper designed a survey as part of a larger study, "The Online Learning Resources in Higher Education," supported by Slovenian Research Agency (ARRS) fund for young doctoral researchers. Andreja Istenič Starčič was nominated as a mentor in 2011 (No. 6316-3/2011-784) and her work also is financially supported by Slovenian Research Agency (P2-0210). Maja Lebeničnik was selected as a young researcher in 2012 (No. 2158). In 2017, the authors were invited to conduct a survey within the University of Ljubljana's project "The Integration of Information and Communication Technology in the Higher Education Pedagogical Process." The current paper was written to examine the pre-covid 19 situation.

\section{$7 \quad$ Authors}

Andreja Istenic, $\mathrm{PhD}$, is professor in didactics at University of Primorska and University of Ljubljana, Slovenia. Her teaching and research interests include instructional design, educational technology, teacher education and professional development, online learning, digital play, research evaluation, and particularly, interdisciplinary research. Andreja was editor of British Journal of Educational Technology and is member of editorial boards in Educational Technology Research and Development, International Journal of Emerging Technologies in Learning, Education and Self Development. Andreja has served as a visiting professor at the University of North Texas, Macquarie University Sydney. Currently, she is serving as visiting professor at Kazan Federal University. Andreja is author of the book Educational technology and construction of authentic learning environment.

Maja Lebenicnik, PhD completed her doctoral study as a young researcher and is now working as an assistant professor in psychology at the University of Primorska 
Paper-How Communion and Agentic Beliefs Predict Technology-Supported Formal and Informal...

Faculty of Education. Her research interests are online learning resources and psychological factors of online learning.

Article submitted 2021-10-03. Resubmitted 2021-11-17. Final acceptance 2021-11-18. Final version published as submitted by the authors. 